\title{
Social Justice Innatural Resources Explosion in Vietnam Currently Looked at the Aspect of Benefits
}

\author{
Associate Professor. Dr. Le Van Doan \\ Hanoi National University of Education, Vietnam \\ Dr. Ho Cong Duc \\ Hanoi National University of Education, Vietnam \\ Dr. Cao Thi Sinh \\ Hanoi National University of Education, Vietnam
}

\begin{abstract}
Social justice is always a lofty goal which humanity targets at. However, for the sake of dominance, the issue of social justice is causing a wide range of challenges. Therefore, in addition to generalizing some general theoretical issues about social justice, this article raises a number of issues of social justice of the natural resources exploitation in Vietnam and the meaning of studying this issue for Vietnam's socio-economic development now.
\end{abstract}

Keywords: justice, equality, benefits, natural resources

DOI: $10.7176 / \mathrm{RHSS} / 9-12-03$

Publication date:June $30^{\text {th }} 2019$

\section{Introduction}

Social justice implementation has always been a matter of concern since humanity has appeared so far. Even from primitive times, although people lived in a herd style, living in stumps and caves, it was not the reasonfor the fact that justice was not paid enough attention. The development of human society is getting higher and higher, the issue of social justice is more and more concerned. In the history of human society, in different stages, social justice implementation is different as well. In a society with class, the issue of justice is classified, opposing classes, the benefits often belong to the ruling class as well as the power class. Today, social justice implementation in all areas in general and social justice implementation in the exploitation of natural resources in particular are posing a lot of problems need to be addressed because natural resources are the common property of the whole society but being exploited by a group of exploiters as their own. This causes social inequality in enjoying benefits from the exploitation of natural resources in Vietnam at the moment. This is a problem that has been happening, causing urgent matters in public opinions that we need to study and solve in order to promote the sustainable development of the society.

\section{Content}

\subsection{Social justice - is the goal and measure for social development}

Social justice is a concept that has been mentioned by thinkers and scientists throughout history, which is a high desire, a beautiful goal that humanity targets at. However, depending on different historical periods, social justice issues are also expressed differently, however, it is found that the implementation of social justice is a measure for the progress and the developmentof human society.

Justice means "everyone can be in reality for developing the same personality, talent, ability and have duty to work for the sake of social collectives"1. Justice can also be interpreted as all citizens enjoy equal and take equal responsibility for the rights and obligations of a citizen. In the history of the development of human society, since the society appeared in class, social justice issue has been paid special attention by all classesin thesociety. Solving conflicts of interest between this class and other classes to bring social justice to all people is the driving force for social development, it is a measure of social progress and human liberation.

Society develops from low to high, through changing socio-economic forms according to its objective rules. The change of these socio-economic forms by other socio-economic forms begins with the development of production forces. When the production force develops, it will lead to the change of production relations to be suitale with it. However, the change in production relations is not possible early, one-way but completely complicated, but sooner or later, the old production relations are also replaced by new production relations to meet the growing production force. The replacement of this production relationship always occurs in the direction of progress, thereby making society more and more progressive and fairer.

Social justice implementation is a lever to promote the progress of socio-economic development and is a goal of people liberation. However, the practical application is very difficult and complicated. In a classified society,

\footnotetext{
${ }^{1}$ Huu Ngoc (1987), Simplified Philosophical Dictionary, Professional university and high school Publisher, Hanoi, page 98.
} 
the ruling class always desires for a greater benefit, leading to a formal implementation of justice. For example, "the bourgeoisie only considers justice in the form of formal equality, before the law, regardless of the situation of social inequality caused by private regimes for means of productionand the oppressive exploitation of workers" ${ }^{2}$. Therefore, social justice implementation with a formal class, social inequality has not been resolved, when justice which is resolved in the perspective of social equality will be the driving force to promote social development towards the progress.

Therefore, in the process of socio-economic development, even though society has created a lot of socioeconomic achievements, if that society is still in classes, the problem of social justice has not yet done. Thus, despite the means of production of society, especially those who have not been liberated, have not escaped from oppression, exploitation, injustice, social justice has not been implemented.

It can be said that, when society is able to liberate people from oppressive exploitation, injustice is gradually removed, social equality is implemented, creating favorable conditions for people to develop comprehensively, then employees will follow the capacity and enjoy according to labor, social justice will gradually become a reality in new society. Nevertheless, social justice really does not only follow the capacity and enjoyment of labor but also depends on the nature and characteristics of each person, each age to have a harmonious distribution of benefits among all people in society. For example, children, the elderly, the disabled, people who are not involved in the production process, are still entitled to social security regimes to maintain and develop. Thus, when people's consciousness is enhanced, science develops, differences in class are abolished, the difference between urban and rural areas is no longer available, then material and spiritual wealth distributed on demand, social security is ensured, social justice is fully implemented.

From the practical summary of social justice implementation in human history, the Vietnam Communist Party has determined from the beginning that social justice is always one of the highest goals of socialism. Through the Congresses, the Vietnam Communist Party always emphasizes social justice in all fields, first of all in the economic area. At the $7^{\text {th }}$ National Congress, the Vietnam Communist Party affirmed that: "Economic growth must be associated with social progress and justice in every development step." ${ }^{3}$ During the period of international integration with the successes achieved in the fields, the Vietnam Communist Party always upholds social justice. The document of the $8^{\text {th }}$ National Congress of the Vietnam Communist Party stated that: "Harmonious combination of economic growth and justice implementation and social progress creates a strong change in resolution which resolves a lot of pressing social issues, repelling negative, injustice and social evils" ${ }^{4}$.

The development of economy and society after opening integration has brought about a wide range of opportunities for the country but also a lot of challenges, such as the problem of distribution of benefits and ecological environment are arising many problems influencing the process of the country's sustainable development, so at the $9^{\text {th }}$ National Congress of the Vietnam Communist Party, itwas affirmed that: "Rapid, effective and sustainable development, economic growth is sometimes with making progress, social justice and environmental protection"5. When society mobilizes and develops with the development of science and technology, the implementation of justice in the distribution of benefits is always set, so at the $10^{\text {th }}$ National Congress of the Vietnam Communist Party, it was stated: "Making progress and social justice right in each step and each development policy...Implementing the distribution system mainly according to labor results, economic efficiency, and at the same time the level of capital contribution and other resources and through social welfare"6. We all know that, social justice is always a goal of human, it shows the humanity, and it is an ideal goal for society to develop sustainably, it is also a driving force for social development and for improving better and better.

The struggle for equal rights, especially justice in economic interests, is always the motivation for the society to develop. In the document of the $11^{\text {st }}$ National Congress of the Vietnam Communist Party, it was affirmed that: "closely and rationally combining economic development with cultural and social development, implementing social progress and justice. Assembly right in every step and every policy..." ${ }^{7}$. At the $12^{\text {nd }}$ National Congress of the Vietnam Communist Party, it was affirmed that: "Closely and harmoniously link economic development with cultural development and implementation of social progress and justice, improve people's lives" ${ }^{8}$. Therefore, it can be seen that, throughout the historical periods, the Vietnam Communist Party always has a consistent view of attaching importance to economic development, linking economic development with social justice and social progress implementing social justice is one of the driving forces for sustainable socio-economic development of the country. Only when we develop the economy associated with social justice and the social justice is ensured, so the new economic development can be sustainable. Therefore, it can be seen that social justice is one of the

\footnotetext{
${ }^{2}$ Huu Ngoc (1987), Simplified Philosophical Dictionary, Professional university and high school Publisher, Hanoi, page 98.

${ }^{3}$ Vietnam Communist Party (1991), Document of the 7th National Congress, National Political Publisher, Hanoi, page 53.

${ }^{4}$ Vietnam Communist Party (1996), Document of the 8th National Congress, National Political Publisher, Hanoi, page 203.

${ }^{5}$ Vietnam Communist Party (2001), Document of the 9th National Congress, National Political Publisher, Hanoi, page 162.

${ }^{6}$ Vietnam Communist Party (2006), Document of the 10th National Congress, National Political Publisher, Hanoi, page 77-78.

${ }^{7}$ Vietnam Communist Party (2011), Document of the 11st National Congress, National Political Publisher, Hanoi, page 79.

${ }^{8}$ Vietnam Communist Party (2016), Document of the 12nd National Congress, National Political Publisher, Hanoi, page 77.
} 
goals and a measure of the progress and development of human society.

Although the issue of social justice in the process of economic development has been concerned throughout the history of mankind, but when applied to the process of socio-economic development, more and more social justice issues occur. It is the imbalance between this industry and other industries, this sector with another sector or the social inequality in a particular industry. One of the sectors in Vietnam today poses a number of social justice issues is the natural resources exploitation.

\subsection{Social justice in the exploitation of natural resources in our country - a number of issues}

As mentioned above, social justice is always a measure of social progress and a goal of sustainable development that any society is aiming at. This is also a problem identified by the Vietnam Communist Party through its Congress Documents. However, at present, a lot of industries with social justice issues are posing many challenges, hindering the development, causing pressing in public opinion, in which the exploitation of natural resources is one of the industries causing the most pressing and unfairness.

We all know that, "resources are national assets, important resources of the country"9, therefore, benefits gained from the exploitation of natural resources must be distributed equally to all people. However, practicality does not take place as expected, because the natural resources are currently being exploited by a group of exploiters as their own, and the people where natural resources are not entitled to benefits. What should have caused some social inequality problems as follows:

Firstly, the imbalance between people and enterprises exploiting natural resources. Currently, some businesses, for their own sake, have defied the law, exploiting natural resources unconsciously. A lot of businesses consider natural resources as their own, so they can exploit and mine them without paying attention to the common interests of the people and thw whole society, causing social imbalance. To survive, people must always be associated with the natural world, natural exploitation, transforming the natural world. However, it is not so that some businesses blindly exploit natural resources, despite allcommon interests of society as well as the long-term interests of the country, especially for non-renewable resources. The benefits gained from the exploitation of natural resources are often very large, which makes many businesses find ways to exploit and scavenge themselves as much as possible. For example, the exploitation of the two largest gold mines in Quang Nam, Vietnam by the two gold companies Bong Mieu and Phuoc Son of Besra Group (Canada), the only foreign enterprise allowed to exploit and export gold at Vietnam in the past time. After nearly 12 years, this company exploited and dug more than 6.9 tons of gold of which value was more than 5000 billion VND, in addition to the tax amount of about 700 billion VND, it also lost hundreds of billion tax revenue ${ }^{10}$, people in the two gold mines have not only benefited from this resource, but also suffered from environmental pollution, after Besra left. Thus, it can be seen that the problem of inequity between people and enterprises exploiting natural resources is very painful today.

Secondly, the inequity between true people and some officials who tend to degenerate, embezzlement, corruption and waste during their work and term. This inequity is often expressed in some state management officials, whose authority has the right to abuse their positions and powers to corrupt natural resources for themselves, for their relatives and siblings, for the benefit of the people and the state, they suffer great losses. The issue of embezzlement and corruption on natural resources has been recognized by the Vietnam Communist Party at the $12^{\text {nd }}$ National Congress document when referring to sectors in Vietnam at high risk of corruption: "Management of land use, exploitation of natural resources, real estate, budget revenues, etc." ${ }^{11}$. Behavior of corruptionand waste of some degenerate officials have caused serious economic, political and social consequences, causing conflicts between different types of interests, causing social inequality, rich and poor differentiation, a part of the people get rich quicker, while another part is very poor. For example, in recent years in Dak Nong, Mr. Nguyen Thanh Son, who is the former member of Provincial Standing Committee, has prepared and received dozens of hectares of land not in accordance with the program 135 of the Vietnam Communist Party ${ }^{12}$, causing social inequality and frustration in public opinion.

Third, the inequity of benefit between the true people and some groups of people exploiting illegal natural resources. As mentioned above, natural resources are the common property of the country, but a part of people despite the law exploited illegal resources taking place throughout the country, all kinds of resources such as gold in Nghe An, coal in Quang Ninh, titan in Binh Dinh, Binh Thuan, etc. The appropriation of illegal resources is causing social imbalance for the righteous people, the common interests of the country are being suffered by some people. Illegally appropriated people to serve their own interests. This illegal exploitation causes social imbalance, which is pressing in public opinion. Therefore, it is necessary to have solutions to prevent in time to protect the common interests of the nation, to make it fair in exploiting the natural resources of the country.

\footnotetext{
${ }^{9}$ Vietnam Communist Party (2016), Document of the 12nd National Congress, National Political Publisher, Hanoi, page 141.

${ }^{10}$ See: Mai Phuong, Dao vang van lo, April 25, 2019, https://thanhnien.vn/tai-chinh-kinh-doanh/dao-vang-van-lo-1075003.html

${ }^{11}$ Vietnam Communist Party (2016), Document of the 12nd National Congress, National Political Publisher, Hanoi, page 212.

12 See: Trung Duong, Former member of Provincial Standing Committee asked for dozens of hectares of land 135 because ... poor, 07/04/2019, https://vietnamnet.vn/vn/thoi-su/nguyen-uvtv-tinh-uy -xin-cap-chuc-ha-dat-135-vi-ngheo-kho-520015.html
} 
Thus, the issue of social justice in the exploitation of natural resources in our country today faces a lot of challenges: One is the imbalance between the interests of the people and the interests of the resources exploitation enterprises; Secondly, the imbalance between the interests of the people and the benefits of some degenerate and corruption officials; Thirdly, the inequity between true people and some parts of the people illegally exploiting resources. Natural resources are the common property of the country, but now are being illegally appropriated by some people, while the people in the places where such natural resources are not beneficial, are they also have to bear the heavy consequences of indiscriminate exploitation of the left-over groups. Therefore, the Vietnam Communist Party needs to take timely measures to bring social justice in exploiting the current natural resources in Vietnam. The implementation of social justice in this area will have important implications for the country's socio-economic development process.

\subsection{The meaning of implementing social justice in the natural resources exploitation in Vietnam today}

Social justice is always a measure for social progress, but to make society really fair, it is very difficult to work, therefore, people always struggle to achieve justice to promote social sustainable development. In exploiting natural resources in Vietnam, the struggle to achieve social justice in terms of benefits is very important for the socio-economic development of the country. That is shown as follow:

Firstly, contributing to the justice between people'sinterests and the benefits of enterprises exploiting natural resources, that is, we implement the distribution of equitable benefits from natural resources that businesses exploitable. Since natural resources are the common property of the people and the country, all the benefits that businesses derive from national resource exploitation must be equally distributed. This means that businesses that are legally licensed to exploit must disclose the benefits and how to divide the benefits according to the percentage of the enterprises, to what percentage to the people to ensure harmonious benefits between businesses and people. Equitable distribution of benefits between people and businesses will contribute to promoting a sustainable development of the society. However, at present, many resource mining enterprises find ways to salvage their own benefits, regardless of the interests of other people, regardless of the interests of the nation, which is unacceptable, such as mining companies Bong Mieu gold in Quang Nam in recent years that is a typical example, because the benefits gained only belong to this business, and the people and the country do not gain anything except for the environmental pollutionand loss of natural resources.

Secondly, social justice implementation between people'sinterests and the benefits of some state management officials in the exploitation and use of natural resources will contribute to the creation of equality and justic towards the law. This justice is well implemented, which will contribute to improving people's confidence in the contingent of natural resource managers, believing in the Party's guidelines and instructions and the State's laws and at the same time, contribute to promoting a sustainable development society. The struggle for justice and equality between the interests of the people and the degenerate cadres is an important work, on the one hand, it contributes to countering the abuse of positions and rights for embezzlement, corruption, to extract resources for themselves and the families of those degenerate officials; on the other hand, this struggle has brought about legitimate and fair benefits for the disadvantaged in society, they deserve to receive the benefits in accordance with the guidelines of the Party and the State, but they are subject to some state management who were degenerated.

Thirdly, resolving strictly before the law for some parts of illegal exploitation of natural resources in order to contribute to bringing justice sto all people and at the same time protecting natural resources as the common property of the country. Without strict and timely handling, the common property of the country will be appropriated as a private part by the illegal exploitation department, and the righteous and the state will not gain any benefits but suffer the consequences of the exploitation. We know that every citizen is equal before the law, therefore, it is necessary to strictly handle those who illegally exploit natural resources, they are daily and hourly trespassing the benefits of any legal to serve the interests of individuals and families, and the common interests of the country, they do not need to care. Therefore, implementing social justice will contribute to protecting the common interests of the country and protecting long-term resources for our nation.

Fourthly, when implementing social justice in natural resources exploitation in such aspects as: justice settlement between personal interests and the interests of enterprises in resource exploitation; justice settlement between the interests of genuine people and the benefits of some degenerate officials; or equitably resolve some illegal exploitation departments with the true interests of the people, etc. will be a great motivation to promote social justice in the field of exploiting natural resources in our country today, and at the same time, contribute to creating motivation for other professions to implement social justice. We know that the benefits from natural resources in our country are currently flowing into the pockets of some people, some businesses, even some degenerate officials, etc. which caused social inequality and conflicts in the public opinion in the past time. Therefore, we need to quickly resolve to establish a harmonious, equitable distribution of benefits from the exploitation of natural resources. This is also the motivation to promote society to progress, justice and equality not only in the exploitation of natural resources but also a part of realizing the goal of social progress and justice in the overall process of constructing and developing our country. 


\section{Conclusion}

Social justice is always the highest goal that any society desires towards, but through different historical periods, social justice is expressed variously. In a society with classes, social justice is classified and the benefit is often in favor of the dominant class. Therefore, people always seek to fight to reclaim justice and equality, making the society constantly develop. In order for society to grow and become more progressive, the issue of social justice must be implemented in all fields, all different professions, in which the implementation of social justice in the mining industry of natural resources hold an extremely important position. In Vietnam today, the issue of social justice in the exploitation of natural resources is facinga lot of problems which need to be solved such as the imbalance between people and enterprises exploiting natural resources; the imbalance between true people and some degenerate officials, embezzlement, corruption and waste; the imbalance in benefits between genuine people and some groups of illegal natural resource exploiters, etc. Solving these issues will contribute to social justice in the exploitation of resources. Today's natural resources in Vietnam promote social progress, and contribute to the realization of goals: rich people, strong countries, democratic, fair and civilized societies.

\section{REFERENCES}

1. Hoang Chi Bao (2007), "Social security system and social security policy through 20 years of innovation Achievements, experiences and issues are being set", Journal of Information on ideological work, No. 7.

2. Nguyen Trong Chuan (2006), Global issues in the first two decades of the $21^{\text {st }}$ century, National political publisher, Hanoi.

3. Trung Duong, former member of Provincial Standing Committee asked for dozens of hectares of land 135 because of... poor, 07/04/2019, https://vietnamnet.vn/vn/thoi-su/nguyen-uvtv-tinh-uy -xin-cap-chuc-hadat-135-vi-ngheo-kho-520015.html

4. Vietnam Communist Party (1991), Document of the 7th National Congress, National Political Publisher, Hanoi.

5. Vietnam Communist Party (1996), Document of the 8th National Congress, National Political Publisher, Hanoi.

6. Vietnam Communist Party (2001), Document of the 9th National Congress, National Political Publisher, Hanoi.

7. Vietnam Communist Party (2006), Document of the 10th National Congress, National Political Publisher, Hanoi.

8. Vietnam Communist Party (2011), Document of the 11st National Congress, National Political Publisher, Hanoi.

9. Vietnam Communist Party (2016), Document of the 12nd National Congress, National Political Publisher, Hanoi.

10. Nguyen Tan Hung (2008), "Social justice implementation in Vietnam today, conflict and methods of resolution", Journal of Philosophy, No. 4.

11. Do Huy (2008), "Social justice in Vietnam: Identity and implementation solutions", Journal of Philosophy, No. 5.

12. Nguyen Thi Nga (2007), The relationship between economic growth and social justice in Vietnam during the renovation period - Problems and solutions, Political Theory Publisher, Hanoi.

13. Huu Ngoc (1987), Simplified Philosophy Dictionary, University and Professional Publisher, Hanoi.

14. Mai Phuong, Dao vang van lo, April 25, 2019, https://thanhnien.vn/tai-chinh-kinh-doanh/dao-vang-van-lo1075003.html

15. Le Huu Tang (2008), "Some theoretical and practical issues of the social justice implementation in Vietnam today", Journal of Philosophy, No. 1.

16. Pham Thi Ngoc Tram (2009), Basic theoretical issues of social justice in our country's current conditions, Social Science Publisher, Hanoi. 